\title{
Resenha
}

Review

\section{Direito à Saúde: Análise à luz da Judicialização}

Alethele de Oliveira Santos ${ }^{1}$

O livro em comento, da lavra de dois magistrados federais, é dividido em cinco capítulos, que apresentam conceitos acerca do direito à saúde, sua aplicabilidade nos processos judiciais e várias análises dos autores sobre a atuação do Poder Judiciário Brasileiro nessa esfera.

Merece atenção o prefácio do ex-ministro do Supremo Tribunal Federal (STF) Teori Albino Zavascki que indica as "escassas convergências" da doutrina e da jurisprudência sobre o tema, em especial, no que diz respeito ao limite das prestações positivas em saúde. A seguir, ainda em sede de apresentação, o professor Álvaro Nagib Atallah, evoca a importância da eficiência, da pesquisa científica e das evidências clínicas, tanto para o sistema de saúde, quanto para o sistema de justiça.

O primeiro capítulo apresenta conceitos essenciais à compreensão do fenômeno da judicialização da saúde, desde a apresentação dos direitos fundamentais, passando pela proibição de seu retrocesso, até o necessário reconhecimento do valor dos diálogos institucionais entre os sistemas de saúde e de justiça. Apresenta, com muito rigor, o limite tênue entre o chamado ativismo judicial e a autocontenção, bem como apresenta critérios - que caracteriza como mínimos - para a teoria da decisão em processos que pautem o direito à saúde.

Já no segundo capítulo, a obra aborda, em suma, as diferentes estratégias utilizadas pelo Poder Judiciário, a partir do papel do Conselho Nacional de Justiça (CNJ) acerca no número crescente de processos judiciais sobre direito à saúde, a interrelação - indissociável - entre os poderes da república na compreensão e responsabilização

\footnotetext{
1 Santos, Alethele de Oliveira. Doutoranda e Mestre em Saúde Coletiva pela Universidade de Brasília (UnB).
} Advogada e assessora técnica do Conselho Nacional de Secretários de Saúde (Conass). E-mail: alethele@ig.com.br. 
sobre o direito fundamental e social à saúde. Nas considerações finais, traça a partir das raízes históricas para o excesso de litigância no Brasil, diagnóstico sobre o fenômeno em pontos específicos - e a necessária redução da judicialização da saúde, sob pena de os sistemas público e suplementar - tornarem-se insustentáveis.

Numa análise sobre o fenômeno da judicialização em si, o terceiro capítulo apresenta, no que foi titulado de "molduras", os princípios a serem perseguidos pelo sistema de saúde e os dados fáticos do cumprimento de tais mandamentos constitucionais. Por conseguinte, apresenta a tríade: "escolhas, escassez e racionamento" que dão sustentação ao elenco de características positivas e negativas da judicialização do setor, indicando o necessário conhecimento da magistratura acerca dos aspectos e consequências, do âmbito coletivo, que envolvem suas decisões.

O capítulo seguinte busca, a partir do diagnóstico apresentado nos itens anteriores, contextualizar a judicialização, numa tentativa de buscar-lhe lógica organizativa, suas possibilidades futuras e um elenco de premissas que buscam o fortalecimento do Sistema Único de Saúde (SUS), como forma de garantia do direito à saúde - individual e coletivamente.

No último capítulo, a obra apresenta a Medicina Baseada em Evidências (MBE), traduzida a partir dos Protocolos Clínicos e Diretrizes Terapêuticas (PCDT), como de fundamental importância para a atuação dos sistemas de saúde e jurídico, inclusive para fins de incorporação de tecnologias no sistema público de saúde.

Certamente transitarão com mais facilidade pelos conceitos apresentados no livro em comento, aqueles de maior intimidade com o direito, como o fez o Ministro Luiz Roberto Barroso, quando o citou em seu voto no recurso extraordinário $566.471^{2}$. Contudo, cabe ressaltar que o livro tem apresentação didática e lógica facilitada aos que militam nos dois sistemas: saúde e jurídico, o que ressalta importância do crescimento qualitativo da produção científica no Direito Sanitário.

2 BRASIL. STF. Acessível em: http://www.luisrobertobarroso.com.br/wp-content/uploads/2016/10/RE566471-Medicamentos-de-alto-custo-vers\%C3\%A3o-final.pdf. Acesso aos 16.06.2017 
Cadernos Ibero-Americanos

de Direito Sanitário

Cuadernos Iberomericanos

de Derecho Sanitario

\section{Referência}

Schulze CJ, Gebran Neto JP. Direito à Saúde: Análise à luz da Judicialização. Porto Alegre (RS) Editora: Verbo. 2015.

Recebido em: 19.6.2017

Aprovado em: 20.6.2017

Como citar este artigo:

Santos AO. Direito à Saúde: Análise à luz da Judicialização. Revista Cadernos Ibero-Americanos de Direito Sanitário. 2017 abr./jun, 6(2):201-203. 